\title{
Sodium and Potassium Currents of Type I Spiral Ganglion Cells from Rat
}

\author{
ERNEST J. MOORE, ${ }^{1,2}$ DEANNE B. HALL ${ }^{1,2}$ and TOSHIO NARAHASHI ${ }^{2}$ \\ From the 'Auditory Neuroscience Laboratory, Department of Audiology and Speech Sciences, Michigan State University, East Lansing, \\ MI 48824-1212, and ${ }^{2}$ Department of Molecular Pharmacology \& Biological Chemistry, Northwestern University Medical School, \\ Chicago, IL 60611-3008, USA
}

\begin{abstract}
Moore EJ, Hall DB, Narahashi T. Sodium and potassium currents of type I spiral ganglion cells from rat. Acta Otolaryngol (Stockh) 1996; 116: 552-560.

Ion channel activity of acutely dissociated type I spiral ganglion cells isolated from rats was investigated using the whole-cell variation of the patch clamp technique. Tetrodotoxin-sensitive sodium current and tetraethylammonium-sensitive potassium current were recorded. With a holding potential of $-80 \mathrm{mV}$, peak sodium currents were generated by depolarizations to membrane potentials more positive than $-50 \mathrm{mV}$. Potassium currents were elicited at membrane potentials more positive than $-40 \mathrm{mV}$. Some cells which did not exhibit sodium current exhibited delayed rectifier potassium currents. Steady-state sodium channel inactivation curve yielded a slope of $12 \mathrm{mV}$ and a half-inactivated potential of $-83 \mathrm{mV}$. Recovery from inactivation of the sodium channel proceeded with a fast and slow time course; recovery began as early as $0.8 \mathrm{~ms}$ and proceeded with a time constant of $7.5 \mathrm{~ms}$. It is concluded that type I spiral ganglion cells are endowed with sodium and potassium channels which are responsible for generation and propagation of auditory nerve action potentials. Key words: cell culture, patch clamp, spiral ganglion cells, sodium current, potassium current.
\end{abstract}

\section{INTRODUCTION}

Type I spiral ganglion cells of the inner ear possess terminals which make up 90 to $95 \%$ of the afferent input to inner hair cells (1). The remaining 5 to $10 \%$ comprise the type II terminals which innervate type II outer hair cells (2). The type I neurons transmit voltage-gated and ligand-gated signals from the cochlea, centrally to the cochlear nucleus $(3,4)$. Interruption of this nerve fiber pathway by a number of physical and chemical agents has deleterious effects on hearing (5).

Very little information is known about ionic conductances of inner ear type I ganglion cells, whether they originate from a non-mammalian preparation such as chicken $(6-10)$, or for mammalian preparations such as guinea pig $(11,12)$ or mouse $(13)$. The purpose of this investigation was to characterize the underlying ionic conductances of type I spiral ganglion cells of a mammal-the rat. To accomplish this goal, we developed a short-term dissociated cell culture of rat spiral ganglion cells. Sodium current and potassium current were recorded from these cells and their underlying ionic properties were studied.

\section{MATERIAL AND METHODS}

Dissociated cell culture. Spiral ganglion cells located within the internal auditory meatus were dissected from rat pups (Sprague-Dawley, E17 and P6-P8). The pups were anesthetized with methoxyflurane (Metofane) followed by rapid decapitation and thoracotomy. Ganglia were isolated and incubated using trypsin $(2.0 \mathrm{mg} / \mathrm{ml}$, type VI, Sigma Chemical Co., St.
Louis, MO) in a $\mathrm{Ca}^{2+} / \mathrm{Mg}^{2+}$-free phosphate-buffered saline (PBS) for $25-30 \mathrm{~min}$ at $37^{\circ} \mathrm{C}$. Embryonic cultures were prepared without using any enzymatic treatment. When enzymes were used, they were followed by rinsing three times using PBS and Dulbecco's Modified Eagle's Medium (DMEM) supplemented with glucose (6 mg/l), Ham's F12 (50 ml, Sigma), 10\% heat-inactivated fetal calf serum (R. H. Lurie Cancer Center, Chicago, IL) and antibiotics (20 U penicillin/ $20 \mathrm{ng}$ streptomycin/ml). A mixture of DNase $(1.5 \mathrm{mg} /$ $\mathrm{ml}$, Sigma) and $\mathrm{MgSO}_{4}(2.5 \mathrm{mg} / \mathrm{ml}$, Sigma) was added after the third wash.

The cells were gently dissociated mechanically by pipetting the media using a fire-polished Pasteur pipette. The cell suspension was plated onto coverslips ( $12 \mathrm{~mm}$, Costar, Cambridge, MA) that had been previously coated with collagen $(0.01 \%)$, placed in plastic 6- or 24-well cell culture clusters. Two $\mathrm{ml}$ of the cell suspension and culture media were added to each of the wells. The cells were cultured in DMEM at $37^{\circ} \mathrm{C}$ in a $5 \% \mathrm{CO}_{2}, 95 \%$ air atmosphere, for as long as they survived without granularity, usually from 2 to 3 days.

Electrical recordings. The whole-cell variation of the patch clamp technique was used to record ionic currents under voltage clamp conditions (14). Suction pipettes made of borosilicate glass capillary tubes (0.8-1.1 mm i.d., Kimble Products, Vineland, NJ) were pulled to have resistance of 1-3 Mohms. Inverted voltage clamp command pulses were applied through the pipette and a pellet/3.0 M KCl-agar bridge was used as a reference electrode. The pipette potentials were maintained at the ground level by 
initially correcting for the liquid junction potential $(-3 \mathrm{mV})$. Membrane currents passing through the pipette were recorded by a current-to-voltage converter consisting of a $500 \mathrm{Mohm}$ feedback resistor and an amplifier (Axopatch 1B, Axon Instruments, Burlingame, CA), and were stored on disks using a computer (PDP 11/73, Digital Equipment Corp., Maynard, MA)/micro-computer (Zenith Z-466x +) patch-clamp work station. Leakage and capacitance currents were digitally subtracted using the $P+P / 4$ protocol (15). Currents were sampled at a rate of $2-50 \mathrm{kKz}$ with a 14-bit A/D converter and filtered with an 8-pole Bessell filter from DC $-5 \mathrm{kHz}$.

Solutions. The external solution consisted of (in $\mathrm{mM}$ ): $\mathrm{NaCl} 140, \mathrm{KCl} 5.0, \mathrm{CaCl}_{2} 2.5, \mathrm{MgCl}_{2} 2.0$, HEPES-acid 5.5, HEPES-Na 4.5, glucose $10, \mathrm{pH}$ adjusted to 7.4 with $\mathrm{NaOH}$, and osmolarity of $310 \mathrm{mOsm}$. Some data were obtained with $70 \mathrm{mM} \mathrm{NaCl}$. When this was done, an equimolar concentration of glucose was used to maintain osmolarity of approximately $300 \mathrm{mOsm}$. When necessary, tetrodotoxin (TTX) $(0.5 \mu \mathrm{M})$ was used to suppress sodium current and tetraethylammonium chloride (TEA-Cl) $(25 \mathrm{mM})$ was used to suppress potassium current. The internal solution consisted of (in $\mathrm{mM}$ ): $\mathrm{CsCl} 110$ (or $\mathrm{KCl}$ for potassium current recording) $\mathrm{MgCl}_{2}$ 2.0, $\mathrm{CaCl}_{2}$ 1.0, HEPES-acid 10, EGTA 11, ATP-Mg 2.0, pH adjusted to 7.4 with $\mathrm{CsOH}$, and osmolarity of $312 \mathrm{mOsm}$. All experiments were conducted at a room temperature of $22-23^{\circ} \mathrm{C}$.

\section{RESULTS}

All voltage clamped data reported herein were obtained from cells with a cross-sectional diameter of $>10 \mu \mathrm{m}$, and were therefore classified as type I spiral ganglion cells. Cells on the cover slip which were less than $10 \mu \mathrm{m}$ in diameter were classified as type II spiral ganglion cells (12). According to Brown et al. (16), however, the size of the cell body is not an accurate indicator to distinguish between type I and type II spiral ganglion cells, particularly as the animal becomes smaller.

Description of spiral ganglion cells from rat. Fig. 1A illustrates a type I spiral ganglion cell (see arrow) and a presumed type I hair cell (see arrowhead) from an E17 rat at one day in culture. The size of the cells ranged from $5 \mu \mathrm{m} 4 \mathrm{~h}$ after plating for an E17 animal to $23 \mu \mathrm{m}$ for a P8 rat measured $4 \mathrm{~h}$ after plating. The plasmalemma of cells from post-natal rats exhibited much more myelin than cells from embryonic animals. Cell shape for the most part was round and exhibited a concave surface shortly after plating. Cells from embryonic animals increased in size over a 3-day period. Cells from post-natal animals did not

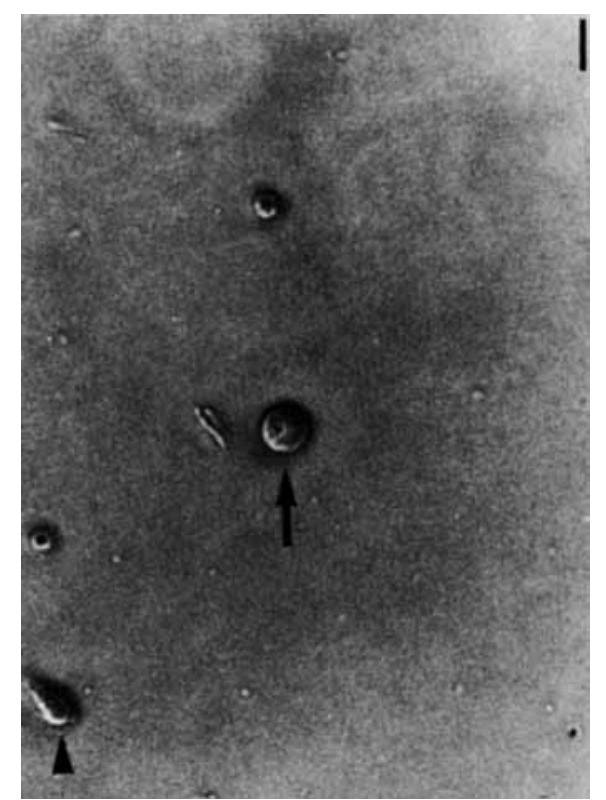

Fig. 1. Photomicrograph (Hoffmann optics) of spiral ganglion cells from E17 rat, $24 \mathrm{~h}$ after plating. A type I spiral ganglion cell (arrow) is located in the center of the field. A presumed type I hair cell (arrowhead) is located at the bottom-left of the type I spiral ganglion cell. A presumed type II spiral ganglion cell is located at the top of the type I spiral ganglion cell. No supporting cellular substrate was used for plating. Scale bar is $5.0 \mu \mathrm{m}$.

increase in size irrespective of the period of time kept in short-term culture, usually 2 to 3 days. After a day or so in culture, both embryonic and post-natal cells became ovoid in appearance, and extended processes which ranged in length from a few microns to tens of microns. The trituration process dislodged most neurite outgrowth, although a few type I cells maintained their bipolar processes after trituration. The trituration process, however, did not always dissociate all cells singularly, so that at times the cover slip consisted of clusters of cells which were usually ensheated in a thick myelin. The myelin sheath may or may not shed from the cells during the incubation period. When the myelin sheath remained attached to the plasmalemma, it was at times problematic to the patch clamp process. For example, if a gigaohm seal was obtained, the whole-cell configuration would at times be compromised due to an inability to break through the outer membrane layer.

Isolation of sodium current. Sodium current was recorded with an external solution of $35 \mathrm{mM} \mathrm{NaCl}$, of which was added $25 \mathrm{mM}$ TEA-Cl, and with an internal solution containing $110 \mathrm{mM} \mathrm{CsCl}$ (Fig. 2). The spiral ganglion cell was $14.25 \mu \mathrm{m}$ in diameter and was cultured from a P6 rat. Depolarizing pulses of $20 \mathrm{~ms}$ duration were applied in $10 \mathrm{mV}$ steps from a 

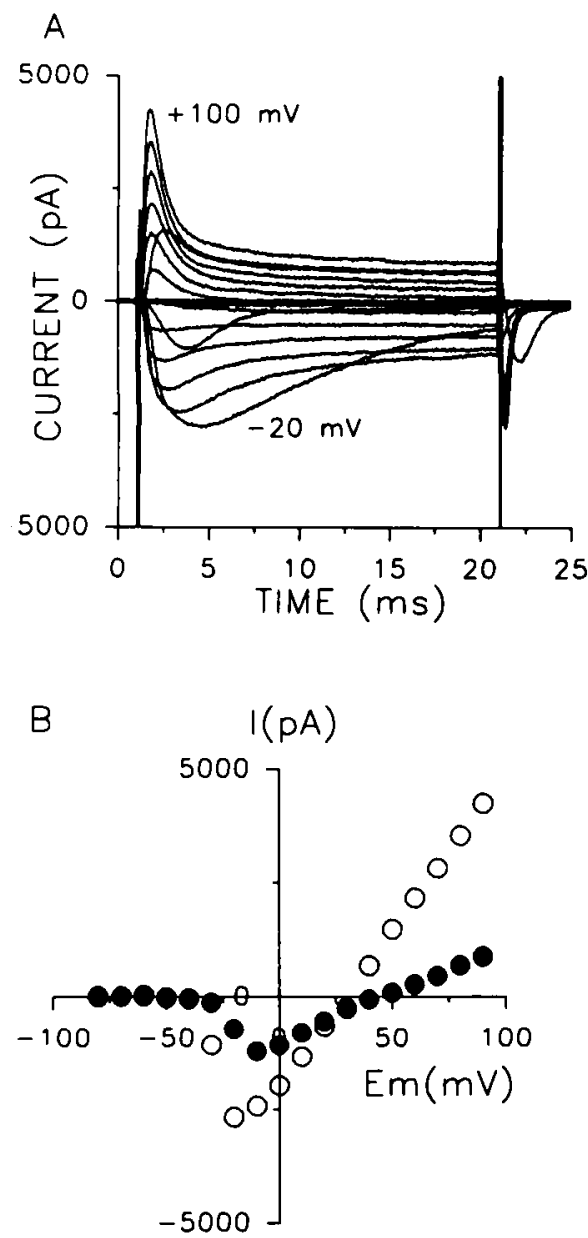

Fig. 2. Sodium currents from rat (P6) type I spiral ganglion cell (diameter: $14.25 \mu \mathrm{m}$ ). (A) Sodium currents obtained to pulses of $20 \mathrm{~ms}$ duration from -80 to +100 , in $10 \mathrm{mV}$ steps. The holding potential was $-80 \mathrm{mV}$. The external solution $(\mathrm{NaCl} 35 \mathrm{mM})$ contained $25 \mathrm{mM}$ TEA-Cl, the internal solution contained $110 \mathrm{mM} \mathrm{CsCl}$. (B) The currentvoltage relation for the data shown in $\mathrm{A}$ for peak sodium current (open circles) and quasisteady-state sodium current (closed circles).

holding potential of $-80 \mathrm{mV}$. Fig. $2 \mathrm{~A}$ shows a family of membrane ionic currents associated with step depolarizations to various levels. The peak currents inactivated partially and were followed by steadystate currents. Inward tail currents were produced upon repolarization of the membrane to the holding potential level. In separate experiments, these currents disappeared after application of $0.5 \mu \mathrm{M}$ TTX, indicating that they were carried through the sodium channel (also see Fig. 3). The current-voltage relations for peak sodium current (open circles) and quasisteady-state sodium current (closed circles) are depicted in Fig. 2B. Channel activation occurred at a membrane potential more positive than $-50 \mathrm{mV}$. The reversal potential was approximately $+30 \mathrm{mV}$
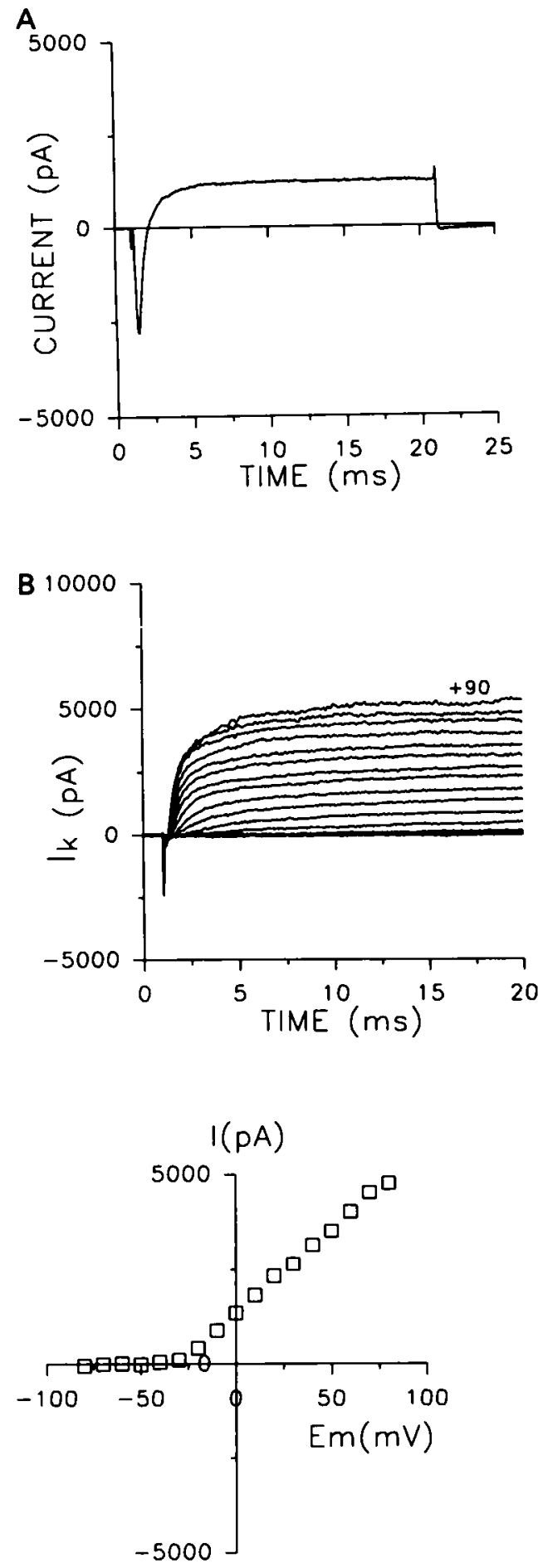

Fig. 3. Inward-going sodium current and outward-going potassium current from rat (P6) type I spiral ganglion cell (diameter: $14.25 \mu \mathrm{m}$ ). (A) Control recording of inward-going sodium current and outward-going potassium current to a $20 \mathrm{~ms}$ pulse stepped to $-20 \mathrm{mV}$, from a holding potential of $-80 \mathrm{mV}$. (B) A family of potassium current records obtained after block of sodium current by tetrodotoxin $(0.5 \mu \mathrm{M})$. $\mathrm{I}_{\mathrm{k}}$, potassium current. (C) Current-voltage relation for the potassium current shown in $B$. I(pA), current in picoamperes. Em ( $\mathrm{mV})$, command voltage in millivolts. 
for both peak and quasisteady-state currents. The currents in Fig. 2A are much slower than those of subsequent figures (Figs. 3, 4 and 6).

Isolation of potassium current. Inward-going sodium current and outward-going potassium current recorded from a P6 rat spiral ganglion cell (diameter: $14.25 \mu \mathrm{m}$ ) are depicted in Fig. 3A. The membrane was depolarized for $20 \mathrm{~ms}$ from a holding potential of $-80 \mathrm{mV}$ to $-20 \mathrm{mV}$. Bath application of $0.5 \mu \mathrm{M}$ TTX blocked inward-going sodium currents revealing uncontaminated potassium currents (Fig. 3B). These outward-going potassium currents were typically observed in most type I spiral ganglion cells. These data indicate that the currents generated by voltage-gated potassium channels present in these cells are the delayed rectifier type. Fig. 3C illustrates the current-voltage relation for the isolated outwardgoing potassium currents. The potassium channels activated to a step depolarization to potentials more positive than $-40 \mathrm{mV}$.

Potassium currents from several spiral ganglion cells could not be completely blocked by extracellular application of $25 \mathrm{mM}$ TEA-Cl. Partial suppression of outward-going potassium currents of a cell (diameter: $14.25 \mu \mathrm{m}$ ) isolated from a P8 rat is illustrated in Fig. 4. Five current traces recorded at one min intervals after $10 \mathrm{~min}$ application of TEA-Cl are superimposed in Fig. 4A illustrating large inward-going sodium currents, and residual outward-going potassium currents. The current records in Fig. 4B represent another example of potassium currents remaining in $25 \mathrm{mM}$ TEA-Cl. The currents were obtained by applying depolarization pulses in $10 \mathrm{mV}$ steps from a holding potential of $-80 \mathrm{mV}$. The potassium currents were suppressed by TEA-Cl but not completely blocked. The current-voltage relationship for the sodium currents (open circles) and potassium currents (filled circles) are illustrated in Fig. 4C.

Several cells tested did not exhibit any sodium currents, or exhibited severely diminished sodium currents, although culture conditions remained consistent, and adequate seals were obtained. The absence of sodium current, however, did not preclude the appearance of outward-going potassium currents. A family of potassium currents of this type are illustrated in Fig. 5A. These data were obtained from a cell isolated from a P8 rat (diameter: $23.75 \mu \mathrm{m}$ ). Fig. 5B shows the current-voltage plot for these data. In those instances in which sodium current was absent, the potassium currents were generally not as robust as when sodium current was present. This might indicate that the cell was not completely healthy.

Steady-state sodium channel inactivation. In the experiment shown in Fig. 6A, the sodium channel was activated by a $20 \mathrm{~ms}$ pulse stepped to a $0 \mathrm{mV}$ from a
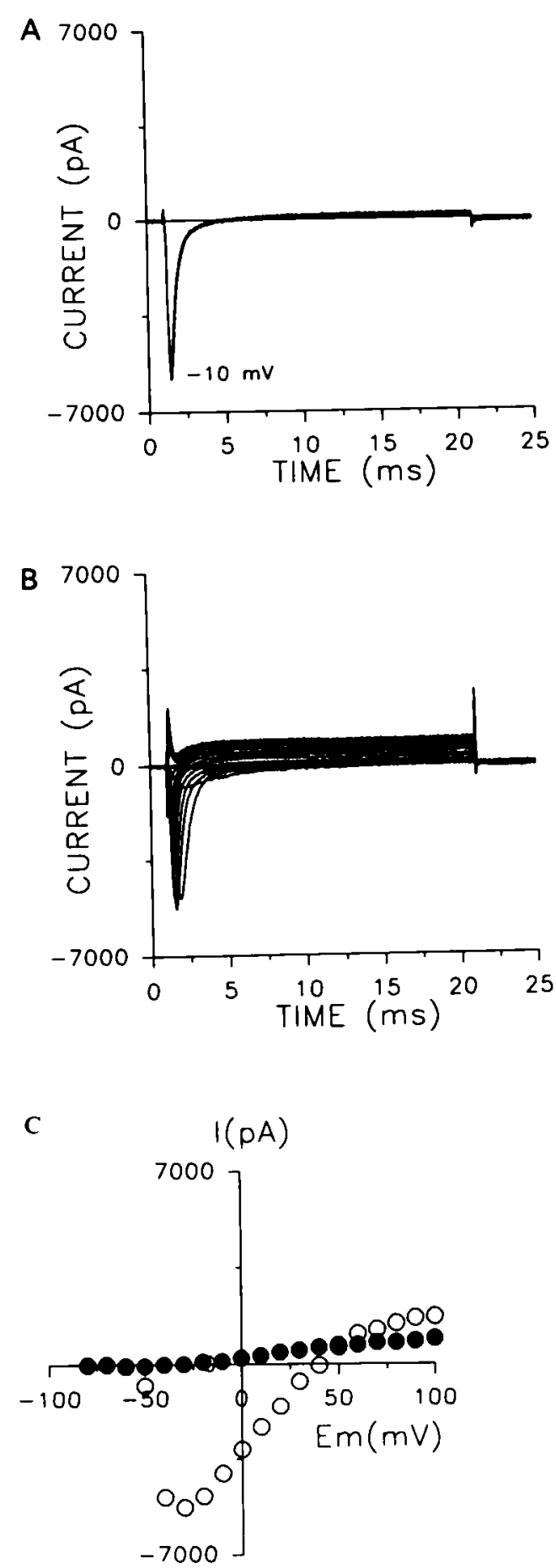

Fig. 4. Partial block of outward-going potassium current by $25 \mathrm{mM}$ TEA-Cl from rat (P6) spiral ganglion cell (diameter: $14.25 \mu \mathrm{m})$. (A) Sodium current records $(n=5)$ obtained at $1 \mathrm{~min}$ intervals to a $20 \mathrm{~ms}$ depolarization voltage pulsed to $-20 \mathrm{mV}$ from a holding potential of $-80 \mathrm{mV}$. A small amount of residual potassium current remains. (B) A family of sodium current records, and a reduced family of potassium current records to bath-applied TEA-Cl (25 mM). (C) Current-voltage relations for peak sodium current (open circles) and partially-suppressed potassium current (closed circles). I(pA), current in picoamperes. Em $(\mathrm{mV})$, command voltage in millivolts. 
A

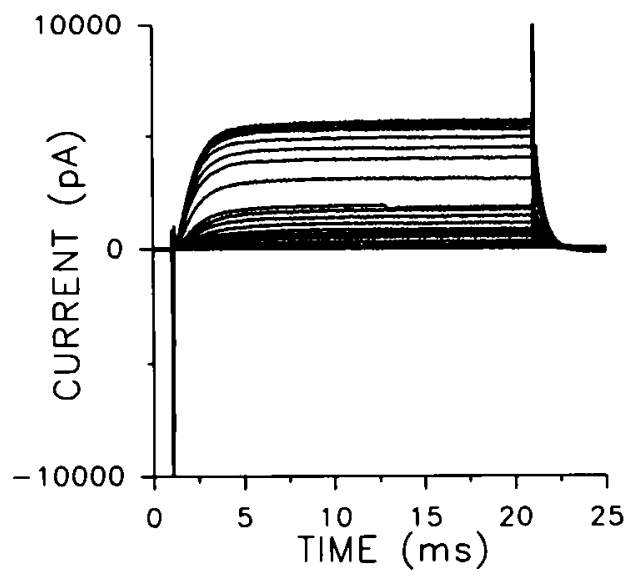

B

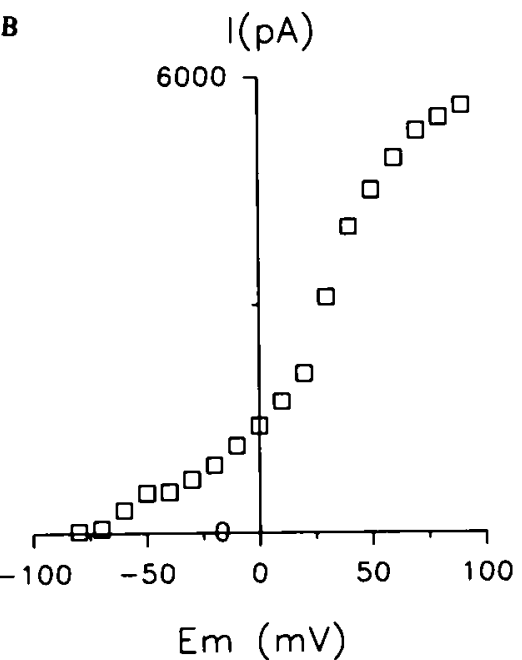

Fig. 5. Outward-going potassium current from rat (P8) type I spiral ganglion cell (diameter: $23.75 \mu \mathrm{m}$ ). (A) This cell displayed only outward-going potassium current, no sodium current was present. (B) Current-voltage relation for the end-point current (measured at $18 \mathrm{~ms}$ ) shown in $A$. I(pA), current in picoamperes. Em (mV), command voltage in millivolts.

holding potential of $-80 \mathrm{mV},-60 \mathrm{mV}$ or $-40 \mathrm{mV}$. No sodium current was generated from a holding potential of $-40 \mathrm{mV}$. With a holding potential of $-60 \mathrm{mV}$ and $-80 \mathrm{mV}$, sodium currents were generated and the time course was faster from $-80 \mathrm{mV}$ than from $-60 \mathrm{mV}$. The potassium channel was activated with holding potentials of $-80 \mathrm{mV}$, $-60 \mathrm{mV}$ as well as $-40 \mathrm{mV}$, and the current amplitude increased with more negative holding potentials. This might indicate that the delayed rectifying potassium channels inactivate very slowly.

The steady-state inactivation of the sodium channel was measured with three type I spiral ganglion cells (diameter: $14.25 \mu \mathrm{m}$ ) isolated from a P6 rat. Potas- sium currents were suppressed with $25 \mathrm{mM}$ TEA-Cl. Fig. 6B illustrates selected current records on an expanded time scale with pre-pulse potentials of $-50 \mathrm{mV},-75 \mathrm{mV}$ and $-100 \mathrm{mV}$, indicating decreases in sodium current with depolarizing prepulses. Following $1 \mathrm{~s}$ pre-pulses to various potentials in $10 \mathrm{mV}$ steps, sodium currents were elicited by a depolarizing pulse to $0 \mathrm{mV}$. The amplitudes of peak sodium currents associated with test pulses were normalized to the maximal value at $-100 \mathrm{mV}$, and are plotted against the pre-pulse potential in Fig. $6 \mathrm{C}$. The data are fitted with curves calculated by the equation: $I / I_{\max }=1 /\left\{1+\exp \left[\left(V_{h}-V_{1 / 2}\right) / k\right]\right\}$, where $V_{h}$ is the holding potential, $V_{1 / 2}$ is the potential at which peak sodium current is one-half maximum and $k$ is the slope factor. The half-inactivated potential was estimated to be $-83 \mathrm{mV}$, and the slope factor was $12 \mathrm{mV}$.

Recovery from sodium channel inactivation. The rate of recovery from sodium channel inactivation was measured by a two-pulse protocol with interpulse interval as the independent variable. A $10 \mathrm{~ms}$ conditioning pulse from a holding potential of $-80 \mathrm{mV}$ to $0 \mathrm{mV}$ was followed by a test pulse to $0 \mathrm{mV}$ at various intervals, and the sodium currents associated with the test pulses were recorded. Fig. 7 illustrates a representative experiment obtained with a type I spiral ganglion cell (diameter: $14.25 \mu \mathrm{m}$ ). Fig. 7A shows three current records obtained at interpulse intervals of $2 \mathrm{~ms}, 10 \mathrm{~ms}$ and $50 \mathrm{~ms}$. The peak sodium currents associated with test pulses normalized to the current associated with the conditioning pulse are plotted in Fig. 7B as a function of pulse interval. The recovery proceeded with a fast and slow time course. The peak sodium began to recover from inactivation as early as approximately $0.8 \mathrm{~ms}$, and continued to recover with a time constant of $7.5 \mathrm{~ms}$. The recovery was complete at approximately $50 \mathrm{~ms}$. Fig. $7 \mathrm{C}$ illustrates the time course of the data in Fig. 7B on an expanded time course of $10 \mathrm{~ms}$.

\section{DISCUSSION}

Auditory information enters the central nervous system by way of the auditory nerve. Type I primary neurons which reside in Rosenthal's canal of the inner ear have their cell bodies within the spiral ganglion of mammals (17) and cochlear ganglion of chickens (6-10). Santos-Sacchi (12) treated the type I spiral ganglion cell body as an internode inserted along the length of the myelinated auditory nerve fiber. He speculated that sodium and potassium conductances of the cell are important for excitability in the form of action potentials that contribute to temporal properties of auditory nerve functioning. 

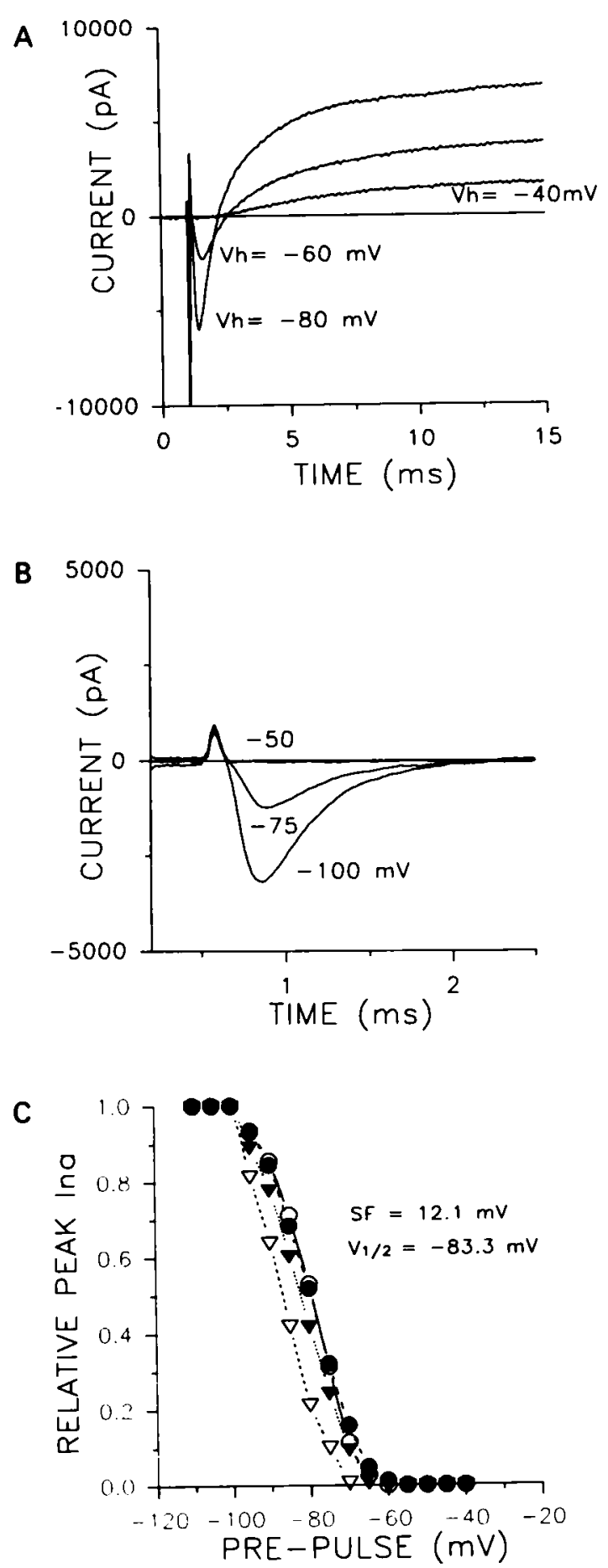

Fig. 6. Effects of holding potential (P6, cell diameter: $14.25 \mu \mathrm{m}$ ) and steady-state inactivation (P6, cell diameter: $14.25 \mu \mathrm{m}$ ) of inward-going sodium current of rat type I spiral ganglion cell. (A) Holding potential was $-80 \mathrm{mV}$, $-60 \mathrm{mV}$ or $-40 \mathrm{mV}$, using a $20 \mathrm{~ms}$ pulse stepped to $0 \mathrm{mV}$. A holding potential of $-\mathbf{4 0} \mathrm{mV}$ completely inactivated the sodium current, but the potassium current was still activated. (B) Inward-going sodium current records (from P7 rat, cell diameter: $14.25 \mu \mathrm{m}$ ) at a pre-pulse potential of $-100 \mathrm{mV},-75 \mathrm{mV}$ and $-50 \mathrm{mV}$. (C) Steady-state inactivation curves for three cells (open and closed circles, open triangles) normalized to the maximal value at
Sodium currents and potassium currents were recorded as part of the present investigation and their underlying contributions to signalling by the auditory nerve are described.

The type I spiral ganglion cells isolated and kept in short-term culture were at times myelinated, but at other times shed their myelin sheath, either during the trituration process or during the incubation stage (12). The presence of myelin is troublesome for the patch clamp process, although the presence of an abundance of myelin of the auditory nerve in vivo probably provides it with an efficient capacitance per unit length. The result of such an anatomical arrangement would cause the action potential to travel much faster in a regenerative manner.

True bipolar neurons for post-natal rats were primarily void of neurite outgrowth until $24-36 \mathrm{~h}$ in cell culture. Type I cells from embryonic cultures, however, exhibited neurite outgrowth as early as $4 \mathrm{~h}$ in culture. Log phase growth of these neurons continued to the limit of survival of the cultures, usually 3 days. Type I cells had a diameter of $15.92 \pm 3.1 \mu \mathrm{m}$ (mean \pm s.d., $n=301$ ). The size of the cells of the rat are smaller than a mean cell diameter of $19 \mu \mathrm{m}$ for the adult guinea pig (12). The type I cells of the present investigation are larger, however, than the values reported for rat (17). These investigators reported a cell size of approximately $8-10 \mu \mathrm{m}$ for rats P8-P10.

The sodium current was reversibly blocked by $0.5 \mu \mathrm{m}$ of TTX $(n=10)$. A number of investigators have observed tetrodotoxin-resistant (TTX-R) as well as tetrodotoxin-sensitive (TTX-S) sodium currents in dorsal root ganglion neurons (18-20). No TTX-R sodium currents were observed in the present investigation with the type I spiral ganglion cells. This is at variance with data obtained with embryonic cochlear ganglion cells of chicken $(6,7)$. However, Yamaguchi $(8,9)$ and Yamaguchi and Ohmori (10) did not observe TTX-R sodium currents in cochlear ganglion cells of chicken.

The steady-state sodium inactivation curve obtained in the present study was relatively steep with a slope factor of $12 \mathrm{mV}$. These data are quite similar to those of Santos-Saachi (12) obtained from adult guinea pig who observed that the steepness was not related to current density of cells. Less steep slope

$-100 \mathrm{mV}$, and plotted as a function of the pre-pulse potentials. The slope factor (SF) of the mean curve (closed triangles) for the three cells (mean diameter: $14.25 \mu \mathrm{m}$ ) is $12 \mathrm{mV}$ and the half-maximal point $\left(\mathrm{V}_{1 / 2}\right)$ is $-83 \mathrm{mV}$. These data are based on the maximum minus the minimum inactivating sodium component. 

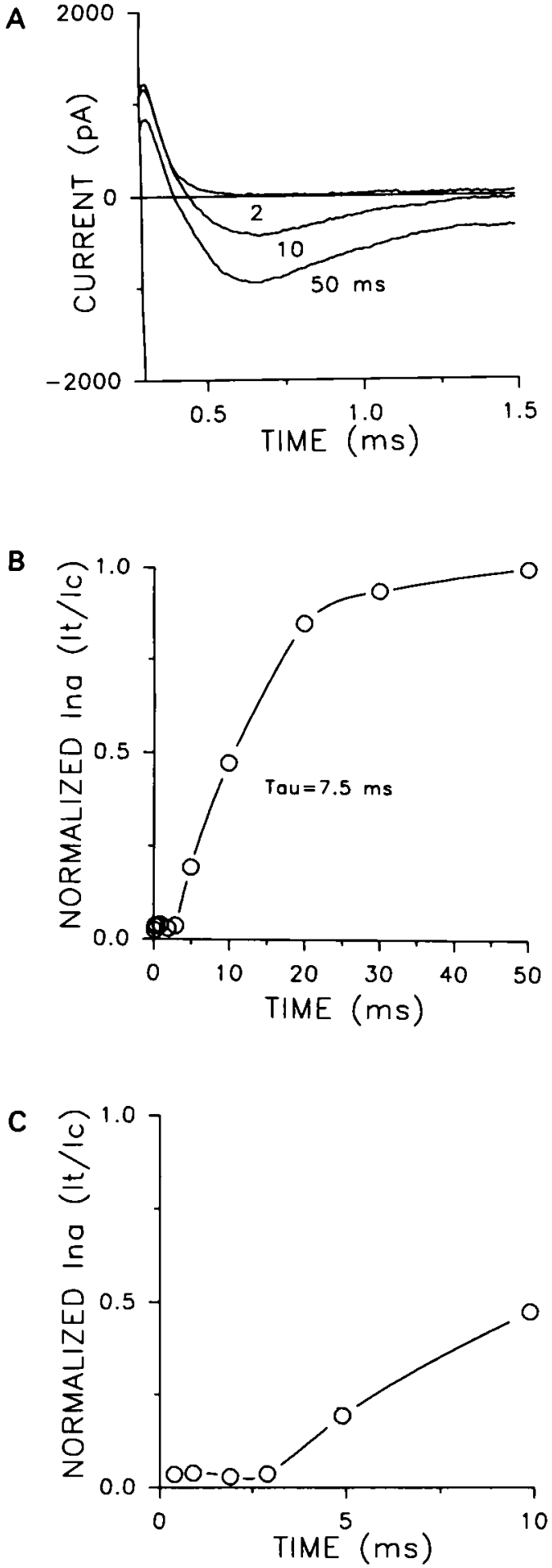

Fig. 7. Rate-of-recovery from inactivation of inward-going peak sodium current from rat (P7) type I spiral ganglion cell (diameter: $14.25 \mu \mathrm{m}$ ). The rate of recovery was determined by a two-pulse protocol separated by various interpulse intervals. (A) Peak sodium currents to interpulse intervals of $2 \mathrm{~ms}, 10 \mathrm{~ms}$ and $50 \mathrm{~ms}$. (B) Rate of recovery of peak sodium current to various interpulse intervals. The Tau is $7.5 \mathrm{~ms}$. $I_{\mathrm{t}}=$ test pulse, $I_{c}=$ conditioning pulse. (C) The first six data points in $B$ plotted on an expanded time scale of $10 \mathrm{~ms}$. factors were reported with other types of cells, e.g., $5.5 \mathrm{mV}$ in neuroblastoma cells $(21)$ and $3.8 \mathrm{mV}$ in DRG cells (22). The $50 \%$ inactivation potential of $-83 \mathrm{mV}$ in the present experiment is more negative than the value of $-66 \mathrm{mV}$ obtained with adult guinea pig spiral ganglion cells (12).

Recovery from sodium channel inactivation was very rapid with a time constant of $7.5 \mathrm{~ms}$ as compared with $31 \mathrm{~ms}$ in mouse neuroblastoma cells (21). This may contribute to the rapid temporal nature of most auditory information. Thus, the sodium channel of type I spiral ganglion cells seems to possess the machinery to accomplish the rapid processing of temporal information and resolving rather high frequency information.

Potassium current from rat type I spiral ganglion cells are primarily of the delayed rectifier type. One important finding was that the current could not be totally blocked by extracellular TEA-Cl at $25 \mathrm{mM}$. When $110 \mathrm{mM} \mathrm{CsCl}$ was present in the pipette solution, potassium current was blocked, but, once again, not completely. Thus, it remains an open question as to whether other potassium channel blockers such as 4-aminopyridine or charybdotoxin may be more potent in the rat dissociated spiral ganglion cell. It is of interest that Santos-Saachi (12) in guinea pig and Sheppard et al. (6) in chicken reported similar findings. Sheppard et al. (6), however, were successful in blocking an A-type outward-going potassium current by 4-aminopyridine. Outward-going potassium currents in the chicken increased in amplitude with development (7). Our data do not allow for developmental comparisons to chicken cochlear ganglion cells.

In some spiral ganglion cells, very large potassium currents ( $\geq 15 \mathrm{nA}$ with $140 \mathrm{mM} \mathrm{KCl}$ inside, $10 \mathrm{mM}$ $\mathrm{KCl}$ outside) were generated (data not shown). In 12 cells, the size of the cell was not a factor, at least for a group of cells that had a cross-sectional diameter of approximately $14 \mu \mathrm{m}(n=6)$, and another group of cells which exhibited a cross sectional diameter of $23 \mu \mathrm{m}(n=6)$. The large potassium current may be involved in generating after-hyperpolarizations which affects the duration of the refractory period of action potentials and modulates the excitability of the cell.

The present results provided a number of instances in which sodium current was absent, but potassium current was present. There are no data for development of the sodium channel or potassium channel in spiral ganglion cells, although auditory reception does not occur in the rat until approximately P8 (17). It is reasonable to suggest that auditory reception would be highly dependent upon the presence of sodium channels, since a majority of the auditory signal transduced by the auditory nerve is encoded as 
action potentials. The presence of delayed rectifier potassium channels would be advantageous for a sensory system in which fast conduction of voltagegated signals is essential (23).

The data obtained in the present study suggest the presence of sodium and potassium currents with activation-inactivation kinetics consistent with other mammalian preparations $(12,13)$. It is tempting to suggest therefore that these underlying ionic currents are related to temporal factors (12) as well as to frequency-dependent factors $(12,24,25)$ underlying auditory nerve activity. For example, we have observed what can be considered as "slow", "intermediate" or "fast" activation-inactivation kinetics. While we have not identified our cells as having as their origin different turns of the cochlear partition, it is tempting to conjecture that "slow cells" (e.g., Fig. 2A) may originate from the more apical end of the cochlea, "intermediate cells" from the middle turn of the cochlea (e.g., Fig. 4A), and "fast cells" (e.g., Fig. 3A) may have as their origin the basal end of the cochlea. That is, tonotopicity (i.e., frequency dependence) is an integral property of the auditory nerve, so that diferent cells from different anatomical regions of the cochlea transmit different frequencies according to their place of innervation along the cochlear partition. Since primary afferents of the auditory nerve and the cochlear nucleus display frequency tuning acccording to their innervation pattern of the basilar membrane of the organ of Corti, the sodium and potassium currents are perhaps reasonable for the underlying bases for this encoding process $(24,25)$.

\section{ACKNOWLEDGEMENTS}

Supported by a NIH-NIDCD Supplement (EJM) to DC00708 (Peter Dallos) and by NS14144 (TN). We wish to thank Jonathan Bloom for expert technical assistance with computers, Nayla Hasan for unfailing help with cell culture, and Peter Dallos as well as Allen Counter for continued support. EJM and DBH wish to thank TN for providing a stimulating and productive laboratory for research.

\section{REFERENCES}

1. Ramón y Cajal $S$. Histologie du système nerveux de l'homme et des vertébrés. Madrid, Spain: Instituto Ramón y Cajal, 1909; 1: 774-838.

2. Spoendlin $\mathbf{H}$. Innervation patterns in the organ of Corti of the cat. Acta Otolaryngol (Stockh) 1969; 67: 23954.

3. von Ebner B. Die Endigung des Schneckennerven im Cortischen Organe. Kölliker's Handbuch der Gewebelehre des Menschen, III. Leipzig: Engelmann, 1903: 944-60.
4. Retzius G. Die Endigungsweise des Gehörnerven. Biolog Untersuchungen, Neue Folfe, III. Leipzig: Vogel, 1892.

5. Schucknecht HF. Pathology of the ear. Cambridge, MA: Harvard University Press, 1974.

6. Sheppard DN, Valverde MA, Represa J, Giraldez F. Transient outward currents in cochlear ganglion neurons of the chick embryo. Neuroscience 1992; 51: 6319.

7. Valverde MA, Sheppard DN, Represa J, Giraldez F. Development of $\mathrm{Na}^{+}$-currents in the cochlear ganglion of the chick embryo. Neuroscience 1992; 51: 621-30.

8. Yamaguchi K. Dissociated cell culture of the cochlear ganglion neuron from the chick embryo and its membrane properties. Biomed Res 1988; 2: 79-82.

9. Yamaguchi K. Ca-channels and glutamate receptorchannel of cultured chick cochlear ganglion neuron. Neurosci Res 1989; 9: S24.

10. Yamaguchi $K$, Ohmori $H$. Voltage-gated and chemically gated ionic channels in the cultured cochlear ganglion neurone of the chick. J Physiol 1990; 420: $185-206$.

11. Nakagawa T, Komune S, Uemura T, Aakaike N. Excitatory amino acid response in isolated spiral ganglion cells of guinea pig. J Neurophysiol 1991; 65: 715-23.

12. Santos-Sacchi J. Voltage-dependent ionic conductances of type I spiral ganglion cells from the guinea pig inner ear. J Neurosci 1993; 13: 3599-611.

13. Davis RL. Complex firing patterns of mouse VIII ${ }^{\text {th }}$ cranial nerve cells in vitro. Assoc Res Otolaryngol Absts 1993; 17: 33.

14. Hamill OP, Marty A, Neher E, Sakmann B, Sigworth FJ. Improved patch-clamp technique for high-resolution current recording from cells and cell-free membrane patches. Pflügers Arch 1981; 391: 85-100.

15. Bezanilla $F$, Armstrong $C M$. Inactivation of the sodium channel. I. Sodium current experiments. J Gen Physiol 1977; 70: 549-66.

16. Brown MC, Berglund AM, Kiang NY-S, Ryugo DK. Central trajectories of type II spiral ganglion neurons. J Comp Neurol 1988; 278: 581-90.

17. Schwartz AM. Auditory nerve and spiral ganglion cells: morphology and organization. In: Altschuler RA, Bobbin RP, Hoffman DW, eds. Neurobiology of hearing: the cochlea. New York: Raven Press, 1986: 27182.

18. Kostyuk PG, Veselovsky VS, Tsyndrenko AY. Ionic currents in the somatic membrane of rat dorsal root ganglion neurons-I. Sodium currents. Neuroscience 1981; 6: 2423-30.

19. Ogata N, Tatebayashi H. Ontogenic development of the TTX-sensitive and TTX-insensitive $\mathrm{Na}^{+}$channels in neurons of the rat dorsal root ganglia. Dev Brain Res 1992; 65: 93-100.

20. Roy ML, Narahashi T. Differential properties of tetrodotoxin-sensitive and tetrodotoxin-resistant sodium channels in rat dorsal root ganglion neurons. J Neurosci 1992; 12: 2104-11.

21. Ogata N, Yoshii M, Narahashi T. Differential block of sodium and calcium channels by chlorpromazine in mouse neuroblastoma cells. J Physiol 1990; 420: 16583.

22. Tatebayashi H, Narahashi T. Differential mechanisms of action of the pyrethroid tetramethrin. J Pharmacol Exp Ther 1994; 270: 595-603. 
23. Weckström M, Laughlin SB. Visual ecology and voltage-gated ion channels in insect photoreceptors. Trends Neurosci 1995; 18: 17-21.

24. Galambos $\mathbf{R}$, Davis $H$. The response of single auditorynerve fibers to acoustic stimulation. J Neurophysiol 1943; 6: 39-57.

25. Ruggero MA. Physiology and coding of sound in the auditory nerve. In: Popper AN, Fay RR, eds. The mammalian auditory pathway: neurophysiology. New York: Springer-Verlag, 1992: 34-93.
Submitted June 29, 1995; accepted October 17, 1995

Address for correspondence:

Ernest J. Moore, Ph.D.

Dept. of Audiology \& Speech Sciences

Michigan State University

378 Comm. Arts \& Sciences Bldg.

East Lansing, MI 48824-1212

USA

E-Mail: Mooreer@Pilot.MSU.Edu 